National and Global Petroleum Assessment

\title{
Assessment of Undiscovered Oil and Gas Resources in the Akita Basin Province, Japan, 2018
}

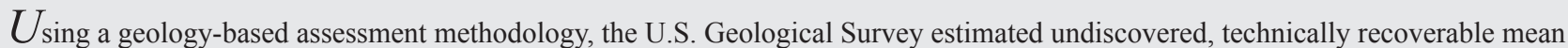
resources of 111 million barrels of oil and 85 billion cubic feet of gas in the Akita Basin Province of Japan.

\section{Introduction}

The U.S. Geological Survey (USGS) quantitatively assessed the potential for undiscovered, technically recoverable conventional and continuous (unconventional) oil and gas resources in the Akita Basin Province of Japan (fig. 1). The tectonic evolution of the Japan arc and the Sea of Japan is well known and forms the basis for the development of the Miocene petroleum system assessed here (Okamura and others, 1995; Wakita, 2013; Van Horne and others, 2017). The Akita Basin is part of a back-arc basin along the western margin of the volcanic Japan arc. Prior to about 30 mega-annum (Ma), the Japan arc was located on the eastern margin of the Eurasian terrane. Regional extension in the Oligocene began about $30 \mathrm{Ma}$, perhaps driven by trench roll-back forces, creating a series of grabens and horsts in the back arc, effectively separating the Japan arc from Eurasia. Following a regional transgression in the Miocene, deep-water conditions prevailed, and many of the grabens were filled with siliceous, organic-rich shales; tuffaceous sandstones; and volcanic rocks. Extension ceased by about $15 \mathrm{Ma}$, and post-rift thermal sag led to further deposition and thermal maturation of source rocks. Beginning in the Pliocene, a major phase of compression resulted in the inversion of many grabens, and petroleum generated from siliceous shales migrated into these structures. As inversion may have caused loss of seal integrity, some of the oil may have been lost or degraded (Okui and others, 2008). The model underlying the assessment is for some oil to have been retained within conventional reservoirs and for some oil to have been retained within the shales as a self-sourced, continuous (unconventional) shale-oil reservoir.

\section{Total Petroleum System and Assessment Units}

For undiscovered oil resources, the USGS defined a Miocene Onnagawa Total Petroleum System (TPS). Within this TPS is the USGS-defined Miocene Onnagawa Shale Oil Assessment Unit (AU), Miocene Onnagawa Shale Gas AU, and Miocene Onnagawa Conventional Oil AU. The Miocene Onnagawa Formation is similar in age and lithology to the Monterey Formation in California, with siliceous, organic-rich, deep-water shales intercalated with sandstones and volcanic rocks. The Onnagawa Formation and equivalent source rocks have total organic carbon values of as much as 5 weight percent and hydrogen index values as much as 650 milligrams of hydrocarbon per gram organic carbon; the source rocks are as much as 500 meters thick (Aoyagi and Iijima, 1983; Ujiie, 1995; Okui and others, 2008; Yokoi and others, 2012; Yokoi and Tsuji, 2015; Suzuki, 2017). Thermal maturation is generally modeled to have begun in the Pliocene, but Onnagawa shales, like the similar-age shales of the Monterey, show vitrinite suppression (Ujiie and others, 2004), which makes mapping the thermally mature source rocks problematic. Because of this, the boundaries of the shale-oil and shale-gas AUs are uncertain.

The geologic model for undiscovered conventional resources is for oil and gas to have been generated from thermally mature siliceous source rocks in the Pliocene; oil and gas migrated updip into traps within inversion structures and diagenetic traps and accumulated in tuffaceous sandstone, porous

volcanic rocks, and fractured shale reservoirs (Aoyagi and Iijima, 1983; Tsuji and others, 2011; Tsuji and others, 2012). Although reservoirs generally exhibit conventional porosity and permeability, some of the potential reservoirs within conventional traps are low permeability and are described as tight reservoirs (Yokoi and others, 2012; Yokoi and Tsuji, 2015). Tight reservoirs within conventional fields are not included in the shale-oil or shale-gas AU areas.

The geologic model for the assessment of shale oil and shale gas is for some portion of the oil or gas to have been retained within thermally mature Onnagawa Formation source rocks. Only the Miocene Onnagawa Shale Oil AU was defined and shale-oil resources assessed. Shale-gas resources were not assessed given the lack of information on the extent of Onnagawa shale within the gas-generation window, such as in the Mogami Trough (Okamura and others, 1995), or the lack of tests that would reflect potential shale-gas resources. Thermal gas has been generated from Onnagawa source rocks, as gas is known from several conventional fields, but the downdip extent of the gas window is unknown.

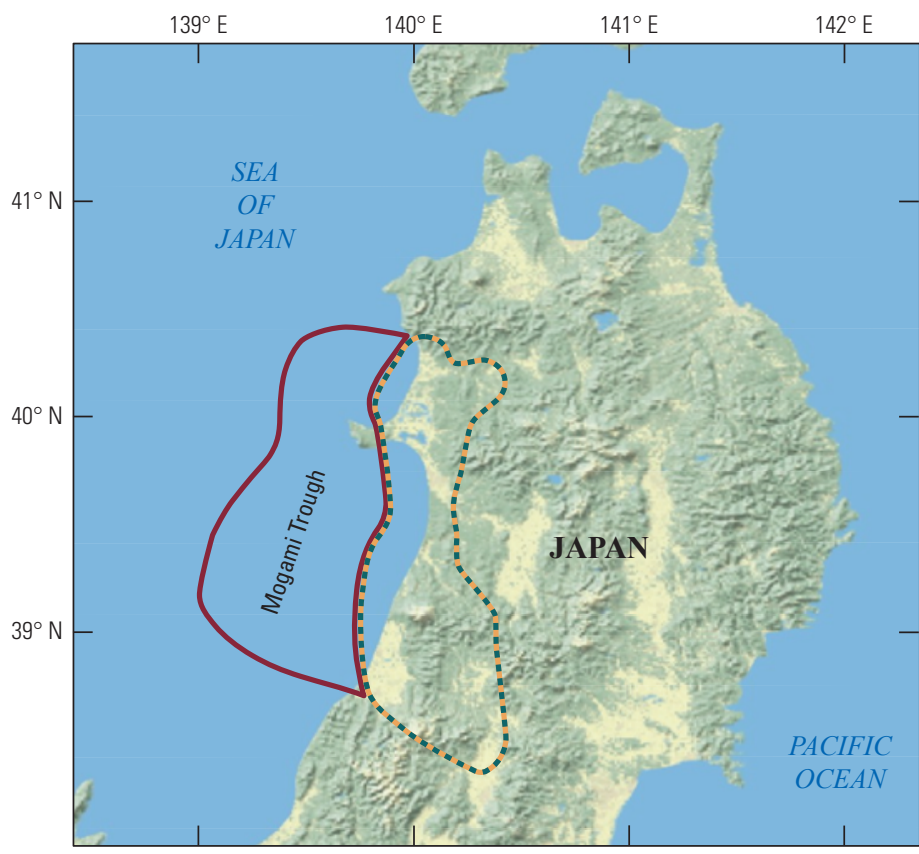

Base map from U.S. Department of the Interior National Park Service

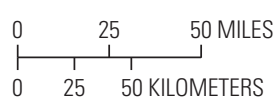

\section{EXPLANATION}

" - . - - . - Miocene Onnagawa Shale Oil AU

- Miocene Onnagawa Shale Gas AU

- $+\ldots$. - Miocene Onnagawa Conventional Oil AU

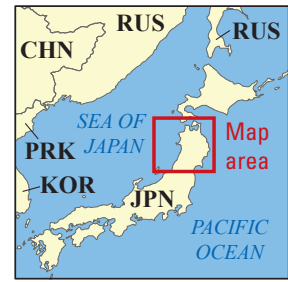

Figure 1. Map showing the location of three assessment units (AUs) defined in the Akita Basin Province of Japan. 
Assessment input data are summarized in table 1. Input data for potential drainage areas, success ratios, and estimated ultimate recoveries for the Miocene Onnagawa Shale Oil AU are modeled after analogs from the Monterey Formation in the United States.
Table 1. Key input data for two assessment units (AUs) in the Akita Basin Province of Japan.

[AU, assessment unit; \%, percent; EUR, estimated ultimate recovery per well; BCFG, billion cubic feet of gas; MMBO, million barrels of oil. Well drainage area, success ratio, and EUR are defined partly using U.S. shale-oil analogs. The average EUR input is the minimum, median, maximum, and calculated mean. Shading indicates not applicable]

\begin{tabular}{|l|c|c|c|c|}
\hline \multirow{2}{*}{ Assessment input data-Continuous AU } & \multicolumn{5}{|c|}{ Miocene Onnagawa Shale Oil AU } \\
\cline { 2 - 5 } & Minimum & Mode & Maximum & Calculated mean \\
\hline Potential production area of AU (acres) & 200 & 825,000 & $1,650,000$ & 825,067 \\
\hline Average drainage area of wells (acres) & 5 & 10 & 40 & 18.3 \\
\hline Success ratio (\%) & 10 & 30 & 50 & 30 \\
\hline Average EUR (BCFG) & 0.003 & 0.005 & 0.02 & 0.006 \\
\hline AU probability & 0.9 & \multicolumn{4}{|c|}{ Miocene Onnagawa Conventional Oil AU } \\
\hline \multirow{2}{*}{ Assessment input data-Conventional AU } & Minimum & Median & Maximum & Calculated mean \\
\cline { 2 - 5 } & 1 & 12 & 36 & 12.8 \\
\hline Number of oil fields & 0.5 & 1 & 100 & 2.5 \\
\hline Size of oil fields (MMBO) & 1.0 & & & \\
\hline AU probability & & & & \\
\hline
\end{tabular}

\section{Undiscovered Resources Summary}

The USGS quantitatively assessed oil and associated gas resources in two assessment units (table 2) in the Akita Basin Province of Japan. For undiscovered, technically recoverable resources, the mean estimated totals are 111 million barrels of oil (MMBO) with an F95-F5 fractile range from 9 to $277 \mathrm{MMBO}$ and 85 billion cubic feet of gas (BCFG) with an F95-F5 fractile range from 6 to $214 \mathrm{BCFG}$. Of the mean total of $111 \mathrm{MMBO}, 79 \mathrm{MMBO}$ are estimated as mean continuous shale-oil resources with an F95-F5 fractile range from 0 to $200 \mathrm{MMBO}$, and $32 \mathrm{MMBO}$ are estimated to be mean conventional oil resources with an F95-F5 fractile range from 9 to 77 MMBO.

Table 2. Results for two assessments units (AUs) in the Akita Basin Province of Japan.

[MMBO, million barrels of oil; BCFG, billion cubic feet of gas; NGL, natural gas liquids; MMBNGL, million barrels of natural gas liquids. Results shown are fully risked estimates. F95 represents a 95-percent chance of at least the amount tabulated; other fractiles are defined similarly. Fractiles are additive under the assumption of perfect positive correlation. Shading indicates not applicable]

\begin{tabular}{|c|c|c|c|c|c|c|c|c|c|c|c|c|c|c|}
\hline \multirow{3}{*}{$\begin{array}{c}\text { Total petroleum system } \\
\text { and assessment units (AUs) }\end{array}$} & \multirow{3}{*}{$\begin{array}{c}\text { AU } \\
\text { prob- } \\
\text { ability }\end{array}$} & \multirow{3}{*}{$\begin{array}{c}\text { Accu- } \\
\text { mulation } \\
\text { type }\end{array}$} & \multicolumn{12}{|c|}{ Total undiscovered resources } \\
\hline & & & \multicolumn{4}{|c|}{ Oil (MMBO) } & \multicolumn{4}{|c|}{ Gas (BCFG) } & \multicolumn{4}{|c|}{ NGL (MMBNGL) } \\
\hline & & & F95 & F50 & F5 & Mean & F95 & F50 & $\mathrm{F} 5$ & Mean & F95 & F50 & F5 & Mean \\
\hline \multicolumn{15}{|c|}{ Miocene Onnagawa Total Petroleum System } \\
\hline Miocene Onnagawa Shale Oil AU & 0.9 & Oil & 0 & 66 & 200 & 79 & 0 & 52 & 160 & 63 & 0 & 0 & 1 & 0 \\
\hline Miocene Onnagawa Shale Gas AU & & Gas & \multicolumn{12}{|c|}{ Not quantitatively assessed } \\
\hline Total undiscovered continuous resources & & & 0 & 66 & 200 & 79 & 0 & 52 & 160 & 63 & 0 & 0 & 1 & 0 \\
\hline Miocene Onnagawa Conventional Oil AU & 1.0 & Oil & 9 & 26 & 77 & 32 & 6 & 18 & 54 & 22 & 0 & 0 & 0 & 0 \\
\hline Total undiscovered conventional resources & & & 9 & 26 & 77 & 32 & 6 & 18 & 54 & 22 & 0 & 0 & 0 & 0 \\
\hline Total undiscovered resources & & & 9 & 92 & 277 & 111 & 6 & 70 & 214 & 85 & 0 & $\mathbf{0}$ & 1 & 0 \\
\hline
\end{tabular}

\section{References Cited}

Aoyagi, K., and Iijima, A., 1983, Reservoir characteristics and petroleum migration in the Miocene Onnagawa Formation of Akita, Japan, in Isaacs, C.M., Garrison, R.E., Graham, S.A., and Jensky, W.A., II, eds., Petroleum generation and occurrence in the Miocene Monterey Formation, California: Pacific Section, Society of Economic Paleontologists and Mineralogists [now the Society for Sedimentary Geology], Los Angeles, California, May 20-22, 1983, Proceedings, p. 75-84.

Okamura, Y., Watanabe, M., Morijiri, R., and Satoh, M., 1995, Rifting and basin inversion in the eastern margin of the Japan Sea: The Island Arc, v. 4, no. 3, p. 166-181.

Okui, A., Kaneko, M.I., Nakanishi, S., Monzawa, N., and Yamamoto, H., 2008, An integrated approach to understanding the petroleum system of a frontier deepwater area, offshore Japan: Petroleum Geoscience, v. 14, no. 3, p. 223-233.

Suzuki, Y., 2017, Overview of unconventional oil and gas potentials and exploration activities in Japan: National Institute of Advanced Industrial Science and Technology, accessed March 27, 2018, at http:/ccop.asia/uc/data/43/docs/ Japan-SUZUKI-UCM7.pdf.

Tsuji, T., Masui, Y., and Yokoi, S., 2011, New hydrocarbon trap models for the diagenetic transformation of opal-CT to quartz in Neogene siliceous rocks: American Association of Petroleum Geologists Bulletin, v. 95, no. 3, p. 449-477.

Tsuji, T., Waseda, A., and Yokoi, S., 2012, Conventional traps in unconventional reservoirs rocks in northern Japan: American Association of Petroleum Geologists, Search and Discovery Article No. 20179, 3 p., accessed March 27,
2018, at http://www.searchanddiscovery.com/pdfz/documents/2012/20179tsuji/ ndx tsuji.pdf.html.

Ujiie, Y., 1995, Petroleum source rocks from the Neogene Tsugaru Basin, northern Honshu, Japan: American Association of Petroleum Geologists Bulletin, v. 79, no. 6 , p. $880-894$.

Ujiie, Y., Sherwood, N., Faiz, M., and Wilkins, R.W.T., 2004, Thermal maturity and suppressed vitrinite reflectance for Neogene petroleum source rocks of Japan: American Association of Petroleum Geologists Bulletin, v. 88, no. 10, p. $1335-1356$.

Van Horne, A., Sato, H., and Ishiyama, T., 2017, Evolution of the Sea of Japan back-arc and some unresolved issues: Tectonophysics, v. 710-711, p. 6-20.

Wakita, K., 2013, Geology and tectonics of the Japanese islands-A review-The key to understanding the geology of Asia: Journal of Asian Earth Sciences, v. 72, p. $75-87$.

Yokoi, S., and Tsuji, T., 2015, Tight oil potential in Neogene Monterey-like biosiliceous shale of Japan: American Association of Petroleum Geologists, Search and Discovery Article No. 51119, 4 p., accessed March 27, 2018, at http:/www. searchanddiscovery.com/pdfz/documents/2015/51119yokoi/ndx_yokoi.pdf.html.

Yokoi, S., Waseda, A., and Tsuji, T., 2012, Shale oil potential in Neogene siliceous shales of Japan: American Association of Petroleum Geologists, Search and Discovery Article No. 80256, 9 p., accessed March 27, 2018, at http:// www.searchanddiscovery.com/documents/2012/80256yokoi/ndx_yokoi.pdf.

\section{Akita Basin Province Assessment Team}

Christopher J. Schenk, Tracey J. Mercier, Marilyn E. Tennyson, Cheryl A. Woodall, Thomas M. Finn, Phuong A. Le, Kristen R. Marra, Stephanie B. Gaswirth, Heidi M. Leathers-Miller, and Ronald M. Drake II

\section{For More Information}

Assessment results are also available at the USGS Energy Resources Program website at https://energy.usgs.gov. 